\title{
\&] $\begin{aligned} & \text { ТРАНСФОРМАШИЯ ПРАВОВЫХ } \\ & \text { И ПОЛИТИЧЕСКИХ СИСТЕМ }\end{aligned}$
}

И.М. Афанасьева

\section{ЭВОЛЮЦИЯ ПОЛИТИЧЕСКОЙ СИСТЕМЫ СЯНГАНА: ОТ БРИТАНСКИХ ТРАДИЦИЙ К ГЛОБАЛЬНОЙ МОДЕЛИ АНКЛАВНОГО РАЗВИТИЯ}

\begin{abstract}
Аннотация: Статья описывает политические преобразования в Специиальном административном округе Сянган со времен колониальной зависимости от Великобритании до настоящего момента. В статье затрагиваются проблемы адаптации местного населения к политическим реформам на разных этапах политического развития Сянгана. Также в данной статье освещены проблемы правовой адаптации политических реформ, проводимых Великобританией, и правовые аспекты передачи Сянгана под юрисдикиию Китая.
\end{abstract}

Ключевые слова: Политология, Сянган, деколонизачия, администрация, политическое образование, автономия, управление, либерализачия, период, мобилизачия

о многом особенности политических процессов в Гонконге предопределены тем, что он является искусственным политическим образованием. При этом система колониального управления Гонконгом достаточно необычна для британских колонийํ. Определяющую роль в ее формировании сыграло несколько факторов. Во-первых, это то, что для Британии Гонконг был важен именно как опора для британских экономических интересов, базировавшихся на принципах свободной торговли. Великобритания получила Гонконг, уже захваченный в результате первой «опиумной войны», в «вечное владение» по Нанкинскому договору 1842 г. А по Пекинской конвенции 1860 г. частью колонии стал полуостров Цзюлун ${ }^{2}$. В 1898 г. колония получила в аренду на 99 лет так называемые Новые территории (376 кв. миль в дополнение к имевшимся 29), причем устанавливая контроль над ними, британской администрации пришлось преодолевать сопротивление местных жителей. Создание условий, выгодных для развития предпринимательства сделало неизбежным применение некоторых западных принципов управления. Свобода торговли и достаточно либеральные методы правления были необходимыми и практически единственными преимуществами бедного ресурсами Гонконга.

\footnotetext{
${ }^{1}$ Лау Ши-Кай. Деколонизация в условиях зависимости и скудность политического лидерства в Гонконге. - Гонконгский институт Азиатско-Тихоокеанских исследований, Китайский университет Гонконга. - 1990

${ }^{2}$ Иванов П.М. Гонконг: история и современность. - М.: Наука, главная редакция восточной литературы. - 1990, с.15.
}

Во-вторых, Гонконг был колонией, созданной на малонаселенной территории - накануне начала колонизации местных жителей здесь было исключительно мало - всего около 70 домохозяйств ${ }^{3}$, существенно больше было население «новых территорий» - почти 600 деревень. Поэтому колониальные власти не могли опираться на коллаборационистски настроенные местные элиты, которых просто не было, поэтому в Гонконге устанавливается прямое британское правление. Но, с другой стороны, колониальным властям практически не приходилось опасаться и антиколониальных восстаний, за исключением периода установления господства на «новых территориях». Жители Гонконга были, в основном, переселенцами, для которых подчинение колониальному режиму было свободным выбором, сделанным по экономическим или политическим причинам.

В-третьих, географическая близость к Китаю, была фактором, который невозможно было игнорировать. Несмотря на автономное развитие, большое влияние на процессы, происходившие в Гонконге, оказывали повороты китайской истории ${ }^{4}$. И то, что до определенного периода слабость Китая, а также экономические и дипломатические соображения не позволяли ему до определенного момента предъявлять требования по восстановлению

\footnotetext{
${ }^{3}$ Иванов П.М. Гонконг: история и современность. - М.: Наука, главная редакция восточной литературы. - 1990, с.9.

${ }^{4}$ Лау Ши-Кай. Деколонизация в условиях зависимости и скудность политического лидерства в Гонконге. - Гонконгский институт Азиатско-Тихоокеанских исследований, Китайский университет Гонконга. - 1990
} 
своего суверенитета над Гонконгом, способствовало укреплению британского господства, которое не сталкивалось ни с внешними, ни с внутренними вызовами.

В 1843 г Гонконгской хартией было установлено, что полнотой законодательной, административной и судебной (до 1853 г. - над всеми подданными Британии в Китае) власти наделяется губернатор. Его указы подлежали утверждению парламентом, и он напрямую подчинялся монарху5. Особенности политики колониальной администрации, которая ограничивала свое вмешательство только теми ситуациями, которые напрямую угрожали европейскому населению, приводили к тому, что социальной сферой, например, здравоохранением, практически никто не занимался. Подобная политика ограниченного вмешательства, а также отсутствие строгого контроля за деятельностью нелегальных организаций позволили революционерам использовать колонию в качестве базы для подготовки своих выступлений. Сунь Ятсен, который учился в Гонконге, и его сторонники также пытались использовать и поддержку местной буржуазии ${ }^{6}$. После Синьхайской революции многие китайские предприниматели перебираются в Гонконг, одновременно обостряется соперничество между китайским и английским капиталом.

Изменения в британской политике в Гонконге соответствовали намерениям нового лейбористского правительства предоставить колониям большую самостоятельность. В этот период обсуждался вопрос реформирования системы управления Гонконгом, целью которой должно было стать расширение представительства китайцев. В 1946 г. они были впервые допущены во многие сферы административного управления.

По мере укрепления политической системы КНР, фактор континентального Китая все в большей степени оказывал влияние на развитие и перспективы Гонконга. Колониальная администрация закрыла границу с КНР в 1950 г. и предприняла ряд мер, направленных против потенциально опасных общественных организаций, проявляя нетерпимость по отношению к сторонникам КНР. Но беспокойство колониальной администрации доставляла и противоположная сторона: в 1956 г. разгорелся конфликт с участием сторонников Гоминьдана, который заставил власти колонии ввести чрезвычайное положение. Беспорядки происходили и в мае 1967 г., когда под влиянием «культурной революции» на материке в Гонконге начались массовые выступления под маоистскими и антиколониальными лозунгами. Властям вновь пришлось прибегнуть к введению чрезвычайного положения. Позиция КПК, высказанная Чжоу Эньлаем, заключалась в том, что

\footnotetext{
${ }^{5}$ Иванов П.М. Гонконг: история и современность. - М.: Наука, главная редакция восточной литературы. - 1990, с.20.

${ }^{6}$ Иванов П.М. Гонконг: история и современность. - М.: Наука, главная редакция восточной литературы. - 1990, с.45.
}

«судьба колонии находится в руках китайского народа»7. Противостояние усилилось и в середине августа хунвэйбины напали на британское посольство в Пекине. Тем не менее, открытого столкновения Великобритании и КНР не произошло, и политические вопросы в отношениях между Гонконгом и КНР долгое время не затрагивались.

Возвращение к проблеме деколонизации произошло после того, как КНР занимает место в Совете Безопасности $\mathrm{OOH}$, а администрация Президента Никсона принимает решение о выводе войск из Вьетнама. Вхождение КНР в Совет безопасности означало признание политики «одного Китая» и, соответственно, признание Тайваня его частью. Это не могло не повлиять на перспективы Гонконга. Тем более, что позиция КНР по этому вопросу была обозначена в документе, адресованном в 1972 г. Комитету ООН по деколонизации. В нем говорилось, что Макао и Гонконг рассматриваются КНР как оккупированные территории ${ }^{8}$. В китайском руководстве практически не было разногласий по поводу того, что с окончанием срока аренды «новых территорий» в 1997 г. они должны быть возвращены Китаю, как и остальная территория Гонконга, полученная Великобританией в результате несправедливых договоров.

Перспективы деколонизации Гонконга, а также стремительный экономический рост (около 9\% ежегодно) подтолкнули реформы 70-х годов. Они были направлены на то, чтобы приблизить колониальное управление к потребностям населения.

С целью приблизить управление к потребностям граждан еще в 1963 г. был создан такой институт как приемная неофициальных членов административного и законодательного советов, куда граждане могли обращаться с жалобами. Впоследствии расширились полномочия местного самоуправления - Городской совет (муниципалитет Гонконга и Цзюлуна) получил финансовую автономию.

Установление прямого управления, ориентированного на поддержание экономической свободы, привело к постепенной, хотя и неоднозначной либерализации в политике. Неоднозначность заключалась в том, что колониальное правительство стремилось сохранить свою политическую монополию. С этой целью правительство блокировало развитие потенциальной оппозиции, иногда используя достаточно жесткие методы ${ }^{9}$ Например, некоторые колониальные законы могли быть применены для

\footnotetext{
${ }^{7}$ Иванов П.М. Гонконг: история и современность. - М.: Наука, главная редакция восточной литературы. - 1990, с.56.

${ }^{8}$ Иванов П.М. Гонконг: история и современность. - М.: Наука, главная редакция восточной литературы. - 1990, с.196.

${ }^{9}$ Харичева М.С. Борьба с коррупцией: опыт Гонконга // Особенности теории и практики нормативного регулирования общественных отношений и правоприменения в различных правовых семьях мира...: материалы международной научно-практической конференции 13 мая 2011 г.
} 


\section{Право и политика 3 (159) • 2013}

подавления оппозиции и ее активных выступлений: это указ о контроле над публикациями, позволяющий запрещать отдельные нежелательные издания, указ о поддержании общественного порядка, позволяющий осуществлять разгон демонстраций, указ о чрезвычайном положении и иммиграционное законодательство, позволяющее запрещать въезд в Гонконг $\Gamma^{10}$.

Вплоть до 1979 года, когда стало ясно, что в конце концов Британия будет вынуждена уступить суверенитет над Гонконгом Китаю, британское правительство было настроено, скорее, против каких-либо реформ. В последующий период реформы начались, их целью было предотвращение развития про-китайских и анти-китайских политических движений в Гонконге, таким образом предполагалось сохранить подчеркнуто нейтральную позицию Гонконга по отношению к КНР. Тем не менее, даже частичное реформирование вызвало противодействие элит, обеспокоенных перспективой потери своего привилегированного статуса ${ }^{11}$.

С другой стороны, колониальное правительство продемонстрировало высокую адаптивность к изменениям в гонконгском обществе при сохранении своего доминирования в политике. Это проявилось в процессе кооптации китайских элит, которые получили статус необходимого, хотя и второстепенного элемента в системе управления. Представители элит включались в состав Исполнительного и Законодательного Советов, а также были представлены в многочисленных совещательных структурах. При условии принятия колониального правления для представителей местных элит была открыта возможность политической, или, скорее, квази-политической карьеры. Таким образом, колониальное господство получало дополнительную легитимность, а местные элиты становились зависимыми от колониальной системы. Включенные в процесс управления элиты неизбежным образом вестернизировались, что облегчалось отсутствием укорененных в Гонконге образованных традиционных элит, которые, как правило, сопротивляются тактике внедрения чужеродных политических форм ${ }^{12}$.

При этом следует отметить, что кооптация представителей местной элиты в систему колониального управления была основана на индивидуальном, а не на групповом принципе. Неизбежным результатом этого стала фрагмен-

\footnotetext{
${ }^{10}$ Иванов П.М. Гонконг: история и современность. - М.: Наука, главная редакция восточной литературы. - 1990, с.214.

${ }^{11}$ Харичева М.С. Борьба с коррупцией: опыт Гонконга // Особенности теории и практики нормативного регулирования общественных отношений и правоприменения в различных правовых семьях мира.... материалы международной научно-практической конференции 13 мая 2011 г.

${ }^{12}$ Джон Флавердью. Последний период власти Великобритании в Гонконге. Этапы деколонизации. - Лондон: Макмиллан пресс LTD.
}

тация местных элит и ослабление связи местных лидеров с базисными социальными группами. Благодаря этому, одним из значимых противоречий в политическом развитии колониального периода стала слабость института политического лидерства.

Таким образом, к переходному периоду Гонконг подошел с не вполне сформированной идентичностью на уровне массового сознания. Элиты Гонконга, как было показано, были инкорпорированы в систему колониального управления. Не претендуя при этом на политическое лидерство, они, прежде всего, отстаивали свои партикулярные интересы. Средний класс также оказался слишком разнородным и дезорганизованным для того, чтобы стать социальной базой для значимой политической силы, преобладание в нем профессиональных и управленческих групп по сравнению с группами интеллектуалов также блокировало развитие политических движений, в отличие, например, от Тайваня.

Поэтому сформированная в годы колониального правления социально-политическая структура, не смотря на высокую экономическую эффективность, к моменту принятия решения об объединении с КНР, оказалась под угрозой. Ее слабость была предопределена такими факторами как концентрация формальной политической власти в руках колониальной администрации и закрытость связанной с ней элиты. Перспектива объединения поставила вопрос о возможном кризисе, связанном с недостатком иных самостоятельных и активных политических сил ${ }^{13}$.

Тем не менее, экономические успехи Гонконга в 70-80- гг. способствовали некоторым социальным изменениям, которые отразились и на политических процессах. Долгое время, во многом благодаря особенностям политической культуры, Гонконгу удавалось избежать проблем, с которыми сталкивались многие стремительно развивающиеся страны, связанных с несоответствием уровней экономического развития и социальной мобилизации. Но уже в 70-е годы начинается формирование общественно-политических организаций, которые высказывались за более активное привлечение гонконгцев к управлению. По своему социальному составу они были разнообразны, но, как отмечала одна из политических активистов, Анна Ву, начавшая свою деятельность именно в такой группе, их объединяло то, то они были рождены в Гонконге и связывали с ним свое будущее ${ }^{14}$. Поэтому стратегия колониальной администрации, ориентирован-

\footnotetext{
${ }^{13}$ Лау Ши-Кай. Деколонизация в условиях зависимости и скудность политического лидерства в Гонконге. - Гонконгский институт Азиатско-Тихоокеанских исследований, Китайский университет Гонконга. - 1990, с.12.

14 Джон Флавердью. Последний период власти Великобритании в Гонконге. Этапы деколонизации. - Лондон: Макмиллан пресс LTD, c.34.
} 
ная на предоставление гарантированной экономической свободы, охраняемой законом, без широких политических свобод исчерпала себя к 70-м годам.

Таким образом, к началу переходного периода Гонконг подошел как общество, по многим характеристикам готовое к демократизации. Но поиск путей развития Гонконга был ограничен перспективой объединения с КНР.

Особенности политических процессов переходного периода были предопределены форматом достигнутых между Великобританией и КНР договоренностей, которые предусматривали передачу КНР. С этой точки зрения, весьма важен тот факт, что, заключив соглашение, КНР все же формально признала британский суверенитет над Гонконгом ${ }^{15}$.

Пытаясь найти компромисс с британской стороной, руководство КНР стремилось также получить поддержку жителей Гонконга. С 1982 г. группы влиятельных представителей гонконгской общественности и бизнеса регулярно приглашались в Пекин для встреч с официальными лицами и КНР и разъяснений по поводу планов объединения и тех возможностей, которые оно должно было принести ${ }^{16}$.

Согласно Совместной декларации, после воссоединения с КНР Гонконг должен был получить статус специального административного района. По сравнению с другими административно-территориальными единицами КНР специальный район обладает широкой автономией во всех областях, кроме внешнеполитической деятельности и обороны. Гарантии сохранения существующего общественного строя предполагали неприкосновенность статуса свободного порта, роли Гонконга как международного финансового центра, независимость финансовой системы, собственной системы налогообложения, сохранение международных соглашений, заключенных ранее, а также всех прав и свобод. Что касается руководства новым административным районом, декларация устанавливала, что глава правительства будет назначаться Пекином на основе результатов консультативных процедур в самом Гонконге.

Центральными политическими процессами переходного периода стали процесс разработки Основного закона и политическая реформа в колонии. Основной закон разрабатывался КНР и подлежал утверждению ВСНП, что соответствовало принципу восстановления суверенитета КНР над Гонконгом. В то же время, британская администрация стремилась осуществить

15 Лау Ши-Кай. Деколонизация в условиях зависимости и скудность политического лидерства в Гонконге. - Гонконгский институт Азиатско-Тихоокеанских исследований, Китайский университет Гонконга. - 1990, с.13.

${ }^{16}$ Джон Флавердью. Последний период власти Великобритании в Гонконге. Этапы деколонизации. - Лондон: Макмиллан пресс LTD, c. 30 реформирование системы управления, которое так долго откладывалось. Таким образом, в Гонконге происходила демократизация, но инициатором ее выступала колониальная администрация, а перспективы преобразований были не ясны, не смотря на то, что КНР обязалась сохранить сложившуюся в Гонконге систему неизменной и одобрила перспективу развития представительства в Совместной декларации. Консервативная направленность реформ, которая критиковалась в процессе общественного обсуждения, оправдывалась стремлением сохранить политическую стабильность в переходный период и не допустить противоборства между полярными политическими силами. Управлявшая Гонконгом в переходный период британская администрация, первоначально избрала политику «конвергенции», согласно которой, будущие изменения должны согласовываться с планами КНР ${ }^{17}$.

В ходе работы над Основным законом происходило агрегирование интересов и формулирование основных политических позиций. На последнем этапе переговоров китайская сторона настояла на том, чтобы ни один законодательный акт Гонконга не рассматривался как приоритетный по отношению к основному закону - таким образом было сведено на нет возможное демократизирующее влияние Билля о правах ${ }^{18}$. Основной закон был оценен как достаточно консервативный, хотя основные принципы - «одна страна - две системы», «высокая степень автономии» и «Гонконгом управляют гонконгцы», нашли в нем свое отражение. Первый принцип заключается в том, что в последующие после объединения 50 лет (до 2047 г.) в Гонконге не будут внедряться социалистические порядки, а капиталистическая система и связанный с ней образ жизни не будут подвергаться изменениям (Статья 5). Высокая степень отведенной особому административному району Сянган автономии заключается в том, что его исполнительная, судебная и законодательная власть достаточно независимы, что закреплено в Статье 2. Третий принцип закрепляется в Статье 3 основного закона, согласно ему органы исполнительной и законодательной власти района должны формироваться из постоянных резидентов Гонконга.

Основной закон разграничил полномочия центрального правительства и региональной власти. Компетенции центра отнесены оборона и внешняя политика (Статьи 13-14). Законы КНР, регулирующие эту сферу, указываются в специальном приложении к

\footnotetext{
17 Джон Флавердью. Последний период власти Великобритании в Гонконге. Этапы деколонизации. - Лондон: Макмиллан пресс LTD, c.55.

${ }^{18}$ Сивиниева O.В. Модель нового государственного управления в Гонконге: от сдержанности к решительным действиям. - ARS ADMINISTRANDI. - №3. - 2011.
} 


\section{Право и политика $3(159) \cdot 2013$}

Основному закону и вступают в силу в Сянгане после одобрения региональным законодательным органом (Статья 18). Охрана правопорядка является функцией региональной власти (Статья 14).

Что касается прав и свобод, то Основной закон гарантирует защиту частной собственности (Статья 6), равенство перед законом, активное и пассивное избирательное право (Статьи 25-26), свободу и неприкосновенность личности (Статья 28), свободу печати и свободу слова, свободу собраний, ассоциаций и шествий, свободу совести, отдельно гарантирует свободу образования профсоюзов и право на забастовку.

После передачи Гонконга КНР регион столкнулся с рядом политических и экономических проблем. В 1997 азиатский экономический кризис наложился на спад, вызванный негативными ожиданиями в связи с объединением. Автономия Гонконга сохраняется и характер политических процессов в новом административном районе существенно отличает его от континентального Китая. Но в то же время, его политическая модель отличается, например, от более демократичной тайваньской ${ }^{19}$.

Специфику политических процессов и политической культуры Гонконга во многом предопределили особенности колониального периода. Применение западных принципов управления и первоочередная реализация принципа свободы торговли не могли не способствовать трансформации общественных отношений и развитию элементов гражданского общества.

Но при этом колониальная администрация ограничивала политическое участие, сохраняя многоступенчатую систему выборов и практикуя кооптацию китайских элит в систему управления Гонконгом. Реформирование системы управления началось в 70-е под воздействием модернизационных процессов, выдвинувших задачу приближения управление к нуждам и потребностям граждан. Особенности колониального управления предопределили достаточно низкую политическую активность гонконгцев, слабость института политического лидерства, приоритет экономических свобод над политическими в массовом сознании.

Не смотря на то, что колониальная администрация перешла к проведению значимых политических реформ только при последнем губернаторе, а некоторые результаты этих реформ были отменены после объединения, опыт активной политической борьбы 1990-х годов имел решающее значение для формирования политического ландшафта сянгана.

Особенностью политического развития Гонконга является то, что активное развитие гражданского общества, гонконгской идентичности и повышение обще-

19 Ван Энбао. Гонконг 1997. Политика переходного периода. Лондон: Линн Риннер Паблишерз. - 1995, с.21. ственного запроса на демократизацию характерны для того периода, когда объединение с КНР стало вполне определенной перспективой. Поэтому формирование политических групп и партий в Гонконге происходит именно в рамках возникшего на этой почве конфликта. В результате сформировалось два политических лагеря - про-пекинский и демократический, соперничество между которыми до сих пор составляет основное содержание политики в Сянгане ${ }^{20}$.

Институт партий в Сянгане достаточно слаб: часто происходят расколы, а на последних выборах главы администрации фаворитами были беспартийные кандидаты. А существующие партии объединены в два достаточно нестабильных блока. Это связано как с отсутствием всеобщих прямых выборов, так и с особенностями политической культуры. Главный политический раскол в современном Сянгане связан с вопросом о сроках и порядке введения всеобщих выборов, необходимость которых закреплена в основном законе и не оспаривается основными политическими силами.

На момент объединения среди гонконгцев не было единства по поводу политических перспектив региона в рамках КНР. Формирование устойчивых политических предпочтений происходит на фоне мягкого давления, оказываемого со стороны руководства КНР. Соблюдая принципы автономии Сянгана, Пекин стремиться оказывать определяющее воздействие на происходящие в регионе политические события. В конфликтных ситуациях руководство КНР стремится к достижению компромиссов при минимальных уступках.

\section{Библиография:}

1. Лау Ши-Кай. Деколонизация в условиях зависимости и скудность политического лидерства в Гонконге. Гонконгский институт Азиатско-Тихоокеанских исследований, Китайский университет Гонконга. - 1990.

2. Иванов П.М. Гонконг: история и современность. М.: Наука, главная редакция восточной литературы. -1990 .

3. Джон Флавердью. Последний период власти Великобритании в Гонконге. Этапы деколонизации. - Лондон: Макмиллан пресс LTD.

4. Харичева М.С. Борьба с коррупцией: опыт Гонконга // Особенности теории и практики нормативного регулирования общественных отношений и правоприменения в различных правовых семьях мира...:

\footnotetext{
${ }^{20}$ Перспективы демократии в Гонконге: решение администрации КНР в 2007 году. - Отчет Исследовательской службы Конгресса США. - Январь, 10, 2008. - (fpc.state.gov>documents/organization/99498.pdf).
} 
Трансформация правовых и политических систем

материалы международной научно-практической конференции 13 мая 2011 г.

5. Сивинцева О.В. Модель нового государственного управления в Гонконге: от сдержанности к решительным действиям. - ARS ADMINISTRANDI. №3. -2011.

6. Ван Энбао. Гонконг 1997. Политика переходного периода. - Лондон: Линн Риннер Паблишерз. - 1995.

7. Перспективы демократии в Гонконге: решение администрации КНР в 2007 году.-Отчет Исследовательской службы Конгресса США.- Январь, 10, 2008. - (fpc. state.gov>documents/organization/99498.pdf).

\section{References (transliteration):}

1. Lau Shi-Kay. Dekolonizatsiya v usloviyakh zavisimosti i skudnost' politicheskogo liderstva v Gonkonge. - Gonkongskiy institut Aziatsko-Tikhookeanskikh issledovaniy, Kitayskiy universitet Gonkonga. - 1990.
2. Ivanov P.M. Gonkong: istoriya i sovremennost'. - M.: Nauka, glavnaya redaktsiya vostochnoy literatury. - 1990.

3. Dzhon Flaverd'yu. Posledniy period vlasti Velikobritanii v Gonkonge. Etapy dekolonizatsii. - London: Makmillan press LTD.

4. Kharicheva M.S. Bor'ba s korruptsiey: opyt Gonkonga // Osobennosti teorii i praktiki normativnogo regulirovaniya obshchestvennykh otnosheniy i pravoprimeneniya v razlichnykh pravovykh sem'yakh mira...: materialy mezhdunarodnoy nauchno-prakticheskoy konferentsii 13 maya $2011 \mathrm{~g}$.

5. Sivintseva O.V. Model' novogo gosudarstvennogo upravleniya v Gonkonge: ot sderzhannosti k reshitel'nym deystviyam. - ARS ADMINISTRANDI. - №3. - 2011.

6. Van Enbao. Gonkong 1997. Politika perekhodnogo perioda. - London: Linn Rinner Pablisherz. - 1995.

7. Perspektivy demokratii v Gonkonge: reshenie administratsii KNR v 2007 godu. - Otchet Issledovatel'skoy sluzhby Kongressa SShA. - Yanvar', 10, 2008. - (fpc. state.gov>documents/organization/99498.pdf). 